\title{
COMMENT
}

\section{SOVEREIGN IMMUNITY: A MODERN RATIONALE IN LIGHT OF THE 1976 AMENDMENTS TO THE ADMINISTRATIVE PROCEDURE ACT}

The Supreme Court first applied the doctrine of sovereign immunity in 1846..$^{1}$ The origin of sovereign immunity as apphed in suits against the federal government is unclear, ${ }^{2}$ but the doctrine is based on the premise that the United States cannot be sued without its consent. Courts view the federal government's immunity fronı suit as a jurisdictional defect of a plaintiff's suit: the plaintiff can maintain an action against the government only if Congress waives immunity. A federal officer therefore cannot confer jurisdiction by waiving sovereign immunity. ${ }^{3}$

Congress has abohished sovereign immunity im niany imstances by specifically providing for statutory review. of agency action. ${ }^{4}$ In the absence of specific authorization, judicial review of agency action must be based on a general jurisdiction statute. ${ }^{5}$ A plaintiff forced to seek this "nonstatutory review,"6 however, faces the possibility that the jurisdictional defect of sovereign immunity will bar his action.

Congress most recently waived sovereign immunity in 1976 by

1. United States v. McLemore, 45 U.S. (4 How.) 286 (1846).

2. Byse, Proposed Reforms in Federal "Nonstatutory" Judicial Review: Sovcreign Immunity, Indispensable Parties Mandamus, 75 HARv. L. Rev. 1479, 1484 (1962). See notes 12-23 infra and accompanying text.

3. Cramton, Nonstatutory Review of Federal Administrative Action: The Need for Statutory Reform of Sovereign Immunity, Subject Matter Jurisdiction, and Parties Defendant, $68 \mathrm{MicH}$. L. REV. 387, 392 (1970).

4. Examples of the elimination of sovereign immunity are the Tucker Act of 1875,28 U.S.C. $\$ \S 1346,1491$ (1976) (snits based on government contracts); Federal Tort Claims Act of 1946, 28 U.S.C. § 1346(b) (1976); Quiet Title Act, 28 U.S.C. $\$ \S 1346(f), 1402(d), 2409$ a (1976). See notes 38-45 infra and accompanying text.

5. Wright \& Miller, Federal Practice and Procedure § 3568 at $463-4$ (1970).

6. Nonstatutory review is a misnomer because all judicial review in federal courts must be based on statutes. The distinction between statutory and nonstatutory review is whether proceedings are specifically authorized by statute in relation to agency action or whether they are available as general remedies under a general jurisdiction statute. Fuchs, Judicial Control of Administrative Agencies in Indiana, 28 IND. L.J. 1, 11-13 (1952). 
amending section 10 of the Administrative Procedure Act ${ }^{7}$ to "remove the defense of sovereign immunity as a bar to judicial review of Federal administrative action otherwise subject to judicial review." 8 The 1976 amendinents were designed to eliminate the confusion in prior case law concerning nonstatutory review of administrative actions by federal courts. ${ }^{9}$ Nevertheless, the extent to which the 1976 amendments have abolislied sovereign immunity in nonstatutory review actions remains a subject of conflict ainong the federal courts of appeals. The Court of Appeals for the Second Circuit has interpreted the amendments very narrowly, ${ }^{10}$ adding to, rather than clarifying, the confusion that existed before 1976. The Courts of Appeals for the Third and Ninth Circuits, on the otler hand, have interpreted the amendments broadly ${ }^{11}$ and have succeeded in outlining the extent to which the amendments abolish sovereign immunity. The lower courts in these circuits have meaningful guidelines for deciding whether sovereign immunity will bar a claim in nonstatutory review actions.

This comment exannines the historical explanations for the doctrine of sovereign immunity as applied in nonstatutory review actions and the doctrine's rational purposes in inodern society. After discussing the modern rationale for sovereign immunity, the comment looks to the cases decided since the 1976 amendinents to the Administrative Procedure Act to discover if the decisions comport with the doctrine's modern rationale. This comment concludes by suggesting several ways for the courts and Congress to ensure that the doctrine will be rationally and properly applied in the future.

\section{Why SOVEREIGN IMMUNITY?}

\section{A. Historical Explanations.}

Discussing the origin of the doctrine of sovereign immunity in United States v. Lee, ${ }^{12}$ Justice Miller observed that despite the repeated apphication of the doctrine, the "principle has never been discussed or the reasons for it given, but it lias always been treated as established

7. 5 U.S.C. $\$ \$ 701-706$ (1976). For the full text of the amended sections see note 91 infra.

8. H.R. REP. No. 94-1656, 94th Cong., 2d Sess. 1, reprinted in [1976] U.S. CODE CoNG. \& AD. NEws 6121 .

9. See notes 50-84 infra and accompanying text.

10. Estate of Watson v. Blumenthal, 586 F.2d 925 (2d Cir. 1978). See notes $112-29$ infra and accompanying text.

11. Legal Aid Soc'y v. Brennan, 608 F.2d 1319 (9th Cir. 1979), cert. denied, 100 S. Ct. 3010 (1980); Jaffee v. United States, 592 F.2d 712 (3d Cir.), cert. denied, 441 U.S. 961 (1979); Hill v. Umited States, 571 F.2d 1098 (9th Cir. 1978). See notes 132-45 infra and accompanying text.

12. Umited States v. Lee, 106 U.S. 196 (1882). 
doctrine."13 Sovereign immunity existed as part of Englisl1 common law and may have been carried over to colonial America in its English form. Sovereign immunity in its present American forn, however, does not follow the English inodel. ${ }^{14}$ The underlying rationale of English sovereign immunity-that the King as sovereign can do no wrong ${ }^{15}$ - was rejected by the abolition of the monarchy in this country. ${ }^{16}$

In early cases the government asserted a number of practical reasons for the sovereign immunity doctrine. In United States v. Lee ${ }^{17}$ the government argued that the United States would be degraded if it were made a party-defendant to a lawsuit. The Court noted, however, that the government constantly appears in court as plaintiff or prosecutor, and would not be degraded by its additional appearances as defendant. ${ }^{18}$ The Court likewise rejected the government's arguinent that "it would be inconsistent with the very idea of supreme executive power, and would endanger the perfornance of the public duties of the sovereign, to subject him to repeated suits . . . at the will of any citizen . . . ."19 The Court stated: "As no person in this government exercises supreme executive power, or perforins the public duties of a sovereign, it is difficult to see on what solid foundation of principle the exemption from liability to suit rests." 20 The notion of sovereign immunity based on supreine executive power is wholly inconsistent with the American form of government. The government's argument in Lee was essen-

13. Id. at 207.

14. The conclusion that American sovereign immunity is not based on the English doctrine is supported by the absence of any inention of sovereign immunity in the Constitution.

15. Byse, supra note 2 , at 1484 .

16. Sovereign immunity in England never barred rehef completely. Rather, in seventeenthcentury England, subjects of the King could petition for a suit against the Crown. In any given case a plaintiff might thus be permitted to proceed against the sovereign. L. JAFFE, JUDICIAL Control of ADMINISTRATIVE ACTION 197 (1965).

The eleventh amendment to the Constitution provides no sovereign immunity to the United States. The amendment provides: "The judicial power of the United States shall not be construed to extend to any suit in law or equity, commenced or prosecuted against one of the United States by citizens of another state, or by citizens or subjects of any fore:ign state." Only the states enjoy immunity from suits in federal courts under the eleventh amendment. Byse, supra note 2, at 1484 n.13. Some courts have assumed, however, that the eleventh annendment extends to the states the same immunity already possessed by the federal government. See Cohens v. Virginia, 19 U.S. (6 Wheat.) 264 (1821). See also Hill v. United States, 50 U.S. (9 How.) 386 (1850); United States v. McLemore, 45 U.S. (4 How.) 286 (1846); Osborn v. Bank of the United States, 22 U.S. (9 Wheat.) 738 (1824). This is a different matter than arguing that the amendment itself renders the federal government immune from suit.

17. 106 U.S. 196 (1882).

18. Id. at 206.

19. Id. (quoting Briggs v. Light Boats, 93 Mass. (11 Allen) 157 (1865)).

20. 106 U.S. at 206. 
tially a reformulation of the notion that the king can do no wrong-a notion inappropriate in a country that has no king.

The Supreme Court has stated, as a reason for the doctrine, that the government should not be "stopped in its tracks by any plaintiff who presents a disputed question ...."21 This argument, however, ignores the reahities of judicial review. As Kenneth Culp Davis noted:

The plain, clear, visible reality is, as no one knows better than Supreme Court Justices, that courts imcluding the Supreme Court are constantly interfering with the public administration and constantly stopping the government im its tracks. . . . Many of the great constitutional decisions throughout our history have stopped the government in its tracks and have interfered in public administration. ${ }^{22}$

Professor Davis, in another article, concludes that the only historical support for the sovereign immunity doctrine is "provided by that fourhorse team so often encountered-historical accident, habit, and natural tendency to favor the familiar, and inertia." 23

\section{B. The Modern Rationale.}

One commentator has noted that "[n]o scholar, so far as can be ascertained, has had a good word for sovereign immunity for many years." 24 The question thus arises whether there is any sound rationale for the doctrine's continued vitahity in the federal courts. There are two plausible arguments for some fornn of sovereign immunity. The two provide basic tests for whether a federal court should hear a nonstatutory review action. The first argument is that sovereign immunity "reflects the Constitution's allocation of power among the three branches of government."25 According to this separation-of-powers rationale, a court should ask whether granting the rehef the plaimtiff seeks would encroach upon powers constitutionally committed to another branch of government, most notably the executive branch. ${ }^{26}$ The second argument that may rationally explain the vitahty of the sovereign immunity doctrime is that "official actions of the Government must be protected from undue judicial interference."27 According to this theory, the apphication of the doctrine should be based upon a consideration of "whether the benefits of judicial review of administrative action are

21. Larson v. Domestic \& Foreign Commerce Corp., 337 U.S. 682, 704 (1949).

22. K. Davis, Administrative LaW TREatise $\S 27.00-7$, at 915 (1970 Supp.).

23. Davis, Sovereign Immunity Must Go, 22 AD. L. REv. 383, 384 (1970).

24. Cramton, supra note 3, at 419.

25. Abernathy, Sovereign Immunity in a Constitutional Government: The Federal Employment Discrimination Cases, 10 HARv. C.R.-C.L. L. REv. 322, 323 (1975).

26. Id. 368.

27. Cramton, supra note 3 , at 397. 
outweighed by the possible interference with governmental programs that may result from the grant of relief."'28

The following situation, based on the facts of Jarecki $v$. United States, ${ }^{29}$ illustrates the application of both the separation-of-powers test and the undue-judicial-interference test. Three federal uniformed civilian guards are denied appointment to the Federal Protective Service, a special guard force created by the General Services Adıninistration to protect federal buildings froin terrorist attack. Members of the Federal Protective Service receive a higher GS classification than other uniformed guards. The three persons pass the appropriate civil service examination, but fail the required physical exainination. They bring suit against the General Services Administration and the Civil Service Commission contestimg the legality of the Federal Protective Service and alleging that the agency abused its discretion in refusing to reclassify them.

On these facts, a federal district court would dismiss the suit for lack of jurisdiction because of sovereign minnunity. The separation-ofpowers rationale would suggest that classification of jobs in the Federal Protective Service is not a decision which courts are capable of inaking; the decision should be left to the executive branch. Congress has entrusted the General Services Administration and the Civil Service Commission, both executive agencies, with broad discretion in these inatters. ${ }^{30}$

Application of the undue-judicial-interference test to the Jarecki facts would result in the same outcome. In fact, the Court of Appeals for the Seventh Circuit used this type of argument as an alternative ground for its actual decision in Jarecki. The court stated, "We cannot grant relief that would place 'an intolerable burden on governmental functions, outweighing any consideration of private harm." "31 The court in Jarecki also stated, however, that the saine result would hold even without a consideration of sovereign immunity. ${ }^{32}$

Although both the separation-of-powers test and the undue-judicial-interference test provide justification for the sovereign immunity doctrine, the results these tests produce can often be achieved through resort to other threshold standards of jurisdiction, such as standing or

28. Id. 415. See also Byse, supra note 2, at 1490; Davis, supra note 23, at 384.

29. 590 F.2d 670 (7th Cir.), cert. denied, 444 U.S. 829 (1979). This case was decided after Congress enacted the 1976 amendments to the Administrative Procedure Act, Act of Oct. 21, 1976, Pub. L. No. 94-574, § 1, 90 Stat. 2721 (1976) (codified at 5 U.S.C. $\$ \S 702-703$ (1976)).

30. See 5 U.S.C. $\$ 5101$ (1976); 590 F.2d at 677.

31. 590 F.2d at 675 (quoting Schlafly v. Volpe, 495 F.2d 273, 280 (7th Cir. 1974)).

32. 590 F.2d at 675. The court in Jarecki reached the same conclusion on the grounds of lack of standing, id., and failure to exhaust administrative remedies, id. at 679. 
failure to exhaust administrative remedies, ${ }^{33}$ without resort to such a complex, ill-understood doctrine as sovereign immunity. For this reason, among others, Congress has abolished many of the remnants of sovereign immunity in nonstatutory review actions. ${ }^{34}$ Congress has not, however, completely abolished sovereign immunity. Whenever the doctrine is still apphicable, the courts should use the undue-judicialinterference test and the separation-of-powers test. Both tests are based on identifiable and constitutionally supportable rationales. ${ }^{35}$ They require courts to examine thoroughly the exact nature of the suit and the government interest involved. Deeper examination of these elements by the courts will eliminate inuch of the imjustice imposed through blind application of sovereign immunity. ${ }^{36}$

\section{APPlication OF THE SOVEREIGN IMMUNity Doctrine IN Nonstatutory Review Cases Before 1976: A Maze of IRRATIONALITY}

\section{A. The General Erosion of Sovereign Immunity.}

Originally, sovereign immunity absolutely barred any suit against the federal government. The courts preceded Congress in recognizing the need, in certain circumstances, to refuse to apply sovereign immunity. Although courts recognized the doctrine and applied it im most instances, they also sought to alleviate some of its harshness and injustice. They therefore created the legal fiction of an ultra vires action against public officials. ${ }^{37}$ In this type of action the plaintiff alleged that the officer's conduct violated his rights and that the officer acted with-

33. The general rule is that "[n]o one is entitled to judicial relief for a supposed or threatened injury until the prescribed administrative remedy has been exhausted." Myers v. Bethleliem Shipbuilding Corp., 303 U.S. 41, 50-51 (1938). The rule is not without exceptions, however, because courts will not require a plaintifi to exhaust administrative remedies if exhaustion will cause irreparable injury or the agency has no obvious jurisdiction. See K. DAVIS, supra note $22, \$ 20.01$ (1958 \& 1976 Supp.). In Jarecki v. United States, 590 F.2d 670 (7th Cir.), cert. denied, 444 U.S. 829 (1979), the court found that none of the plaintiffs had "exhausted the extensive remedies provided by the Classification Act, 5 U.S.C. $\$ 5512 ; 5$ C.F.R. $\$ \$ 511.601 \mathrm{et} \mathrm{seq.} \mathrm{.} \mathrm{.} \mathrm{."} 590$ F.2d at 679.

The requirements for standing to bring suit were set forth in two Supreme Court cases, Association of Data Processing Serv. Organizations v. Camp, 397 U.S. 150 (1970) and Barlow v. Collins, 397 U.S. 159 (1970). First, there must be injury in fact. Second, the interest the plaintiff seeks to protect must be "arguably within the zone of interests to be protected or regulated by the statute or constitutional guarantee in question." Association of Data Processing Serv. Organizations v. Camp, 397 U.S. at 153. See generally K. DAvis, supra note 22, § 22.04 (1958 \& 1970 Supp.).

34. See notes 91-100 infra and accompanying text. See also note 5 supra.

35. See notes $25-28$ supra and accompanying text. The tests are based on similar considerations and should therefore yield similar results.

36. See notes 59-70 infra and acconipanying text.

37. Byse, supra note 2, at 1485. 
out legal authorization. If the court found that the officer did act outside his authority, the court would permit the plaintiff's suit and treat it as an action against a private individual. ${ }^{38}$ These lawsuits were either for damages or for equitable rehef. ${ }^{39}$

In many situations this nonstatutory suit was inadequate to meet the needs of citizens demanding redress of their grievances. Congress reacted by enacting a variety of statutes authorizing suits against the government as the need arose. The first such law was the Court of Claims Act of $1855 . .^{40}$ It created the Court of Claims and empowered that court to award damages against the United States in actions arising out of government contracts. Twenty-two years later, Congress expanded the jurisdiction of the Court of Claims and granted concurrent jurisdiction to United States District Courts in certain cases. ${ }^{41}$ Congress later waived government immunity for inany torts committed by government officials, by enacting the Federal Tort Claims Act.42 In addition, the Mandamus and Venue Act of 1962,43 though it did not eliminate any type of sovereign immunity, did facilitate the bringing of nonstatutory review actions. The Act perinitted the federal district courts to issue injunctive or declaratory decrees agamst federal officers to accomplish the same results that a writ of inandamus would have achieved. ${ }^{44}$

Simce 1972 Congress has also permitted private citizens to maintain quiet title actions against the government. ${ }^{45}$ Before 1972 sovereign immunity prohibited landowners from bringing such suits, often creat-

38. R. Jackson, The Supreme Court in the American System of Government 46-47 (1955).

39. Byse, supra note 2, at 1481 .

40. Ch. 122 , 10 Stat. 612 (1855).

41. Tucker Act, ch. 359, 24 Stat. 505 (1887) (current version at 28 U.S.C. $\S \S 507,1346,1402$, 1491, 1496-1497, 1501, 1503, 2071-2072, 2411, 2501, 2512 (1976)). The Tucker Act currently provides for concurrent jurisdiction in the Court of Claims and the United States District Court in all cases arising out of government contracts in which the amount sought in damages is less than $\$ 10,000$. The Court of Claims has exclusive jurisdiction over contract cases worth more than $\$ 10,000.28$ U.S.C. $\$ \S 1346(\mathrm{a})(2), 1491$ (1976).

42. 28 U.S.C. $\$ 1346(b)(1976)$.

43. Id. $\S 1361$.

44. 28 U.S.C. $\$ 1361$ provides: "The district courts shall have original jurisdiction of any action in the nature of mandamus to compel an officer or employee of the United States or any agency thereof to perform a duty owed to the plaintiff:" See Kentucky ex rel. Hancock v. Ruckelshaus, 497 F.2d 1172 (6th Cir. 1974), affd on other grounds sub. nom Hancock v. Train, 426 U.S. 167 (1976); Switzerland Co. v. Udall, 337 F.2d 56 (4th Cir. 1964), cert. denied, 380 U.S. 914 (1965).

Prior to the addition of section 1361, federal district courts, except those in the District of Columbia, could not issue original writs of mandamus. See generally Byse \& Fiocca, Section 1361 of the Mandamus and Venue Act of 1962 and "Nonstatutory" Judicial Review of Federal Administrative Action, 81 HARv. L. REv. 308 (1967).

45. See 28 U.S.C. $\$ 81346(f), 1402$ (d), 2409(a) (1976). 
ing obvious injustices. In the case of Malone v. Bowdoin ${ }^{46}$ for example, a landowner filed a common law ejectment action against a Forest Service officer of the Department of Agriculture. The plaintiff claimed he was the rightful owner of the property and the defendant-officer claimed that the United States held the property under a valid deed. The Supreme Court upheld a dismissal of the suit based on sovereign immunity; ${ }^{47}$ none of the courts hearing the case ever decided the legal status of the title to the property. To rectify this type of injustice, Congress enacted legislation permitting private citizens to bring quiet title suits against the government. ${ }^{48}$

\section{B. Nonstatutory Review Actions: From Lee to Larson.}

While Congress was gradually abolishing sovereign immunity in the areas of contracts, torts, and quiet title actions, the doctrine continued to block a great number of suits against the federal government. In those cases a plaintiff's only resort was to bring an action against a government officer under the legal fiction of ultra vires. ${ }^{49}$ This section will examine the Supreme Court's decisions involving sovereign immunity in nonstatutory review actions. Those decisions created a coinplex and confusing body of case law that led Congress to amend the Administrative Procedure Act in 1976.

The earliest leading case formulating a test for sovereign immunity was United States $v$. Lee. ${ }^{50}$ In that case the plaintiff brought suit to recover eleven acres of land that the government held under a tax deed. ${ }^{51}$ If the tax sale was valid, Lee had no claim to the property, but if the sale was invalid, title would be quieted in Lee. The jury trying the case found for the plaintiff. ${ }^{52}$ On appeal, the government claimed that the federal court could not render judgment in favor of Lee because the judgment would act upon the sovereign without the sover-

46. 369 U.S. 643 (1962).

47. Id. at 648.

48. See note 45 supra. See also H.R. Rep. No. 94-1656, supra note 8, at 8, reprinted in [1976] U.S. Code CONG. \& AD. News 6128.

49. See notes 37-39 supra and accompanying text.

50. 106 U.S. 196 (I882).

51. The property in question was Arlington National Cemetery. Prior to the Civil War the land was used as the home of Robert E. Lee and his family. During the war, the government imposed taxes on the property but when a representative of General Lee tendered the taxes, the revenue agents refused to accept the tender. The agents interpreted the tax statute in question as requiring the actual person against whom the taxes were levied to tender payinent. The land was then put up for a tax sale and purchased by the United States government. The property was used as a military base and a cemetery for Union soldiers. Id. at 197-98.

52. See id, at 199. 


\section{eign's consent. ${ }^{53}$}

Justice Miller, writing for the Supreme Court, noted that the government's sole contention was that anyone who asserted executive authority was absolutely immune from judicial review. ${ }^{54}$ The Court held that the judiciary could not inaintain this type of deference to the executive branch. The idea was "opposed to all principles upon which the rights of citizens, when brought in collision with acts of government, must be determined." 55 Justice Miller's test was, rather, whether the issues presented were clearly capable of being decided by the judiciary. ${ }^{56}$ If the issues were not of the type the judiciary usually decided, the court would dismiss the suit. In a sense, Justice Miller applied a separation-of-powers test. 57

The reasoning and result of the Lee case is sound under both modern rationales for sovereign immunity. ${ }^{58}$ The judiciary was capable of deciding the issues in the case and the decree would not unduly interfere with important governmental functions. The Court therefore found no need for sovereign immunity. Had the Lee formulation remamed the test for immunity there would have been little confusion in determining when a plaintiff can mamtain a nonstatutory action against the government. Unfortunately, the Supreine Court ignored the reasoning in Lee when it decided Larson v. Domestic and Foreign Commerce Corporation ${ }^{59}$ in 1949.

In Larson the plaintiff had contracted with the War Assets Administrator to purchase coal. After a dispute arose over the nethod of payment, the Administrator contracted to sell the coal to a third party. The plaintiff brought suit to enjoin the sale, claiming that title to the coal had already passed to him. ${ }^{60}$ The district court held that sovereign immunity barred the suit.61 On appeal, the Supreine Court identified the issue as whether a suit against an officer was, in effect, a suit against the sovereign. "If it is, it must fail, whether or not the officer might otherwise be suable." 62

53. Id. at 204.

54. $I d$. at 220.

55. Id. at 218-19.

56. Id. at 221-23. "The Circuit Court was competent to decide the issues in this case between the parties that were before it." Id. at 223.

57. See notes 25-26 supra and accompanying text.

58. See text accompanying notes 25-28 supra.

59. 337 U.S. 682 (1949).

60. Id. at 684 .

61. Id. at 685.

62. Id. at 687. 
The Court in Larson then stated a test for deciding whether a suit for specific rehef is not a suit against the sovereign. Two categories of suits would not be barred by sovereign immunity: those suits in which a statute limited the officer's powers and the action complamed of was beyond those statutory powers (ultra vires), and those in which the statute or action was unconstitutional. ${ }^{3}$ For cases in the first category, general allegations of error in the exercise of authority would not be sufficient; the plaintiff would have to allege the exact statutory limitation on the officer's authority.

After formulating the test of ultra vires or unconstitutional action, the Court placed a roadblock in the path of private hitigants sumg a government official. Even if the suit were properly framed to fit into one of the two categories, it might still fail "if the rehef requested [could] not be granted by merely ordering cessation of conduct complamed of but [would] require affirmative action by the sovereign ....."64

Two 1963 Supreme Court cases, Dugan v. Rank ${ }^{65}$ and Hawaii v. Gordon, ${ }^{66}$ further refined the Larson case. Dugan involved a water diversion program conducted by the Department of the Interior. The plaintiff claimed that the Departinent had not legally obtamed the water rights in question and that the diversion of water was trespass and was therefore beyond the scope of the officer's authority. ${ }^{67}$ The plaintiff sought damages for water already diverted and an injunction agamst further diversion. The Supreme Court upheld the dismissal of the suit on sovereign immunity grounds, stating: "The general rule is that a suit is agamst the sovereign if 'the judgment sought would expend itself on the public treasury or doinain, or interfere with the public administration . . . ." "68 According to the Larson-Dugan rationale, a plamtiff not only would have to frame his pleadings to fit either the ultra vires test or the unconstitutional test, but also would have to frame his request for relief so that it would not infrimge on the public treasury or public administration.

In Hawaii v. Gordon the Court made ultra vires actions even more difficult for the private litigant. The Court stated: "The general rule is that relief sought nominally against an officer is in fact against the sov-
63. Id. at $689-90$.
64. Id. at $691 \mathrm{n} .11$.
65. 372 U.S. 609 (1963).
66. 373 U.S. 57 (1963).
67. 372 U.S. at 620.
68. Id. (quoting Land v. Dollar, 330 U.S. 731, 738 (1947)). 
ereign if the decree would operate against the latter."69 The difficulty with this formulation is that any type of relief granted to a private plaintiff in a suit against the government necessarily operates against the government. ${ }^{70}$ The anomaly thus presented was that a person could bring a suit against a federal einployee but the courts could not grant any affirmative rehef if the plaintiff prevailed.

The Larson line of cases fails to comport with the inodern rationale for sovereign immunity. ${ }^{71}$ Larson and its progeny preclude plaintiffs from suing the government, forcing thein to frame suits as ultra vires actions. Under the inodern rationale the courts should determine whether a plaintiff's action would be handled best by another branch of government or whether the relief requested would constitute undue judicial interference. No sound reason exists for dismissing a plaintiff's suit merely because the relief sought would operate against the governinent. 72

The confusion that resulted from the Larson line of cases left lower courts frustrated. Judge McGowan of the Court of Appeals for the District of Columbia Circuit noted that " $[t]$ he doctrine itself is in a considerable state of disrepair, at least in terins of intellectual respectability . . . ."73 Lower courts, recognizing the undue harshness of the Larson test, used different methods to bypass the rule. In Littel v. Morton $^{74}$ the Court of Appeals for the Fourth Circuit examined the Larson line of cases and determined that a mechanical application of that sovereign immunity test would result in dismissal of the case. The court refused, however, to apply the technicalities of the Larson-DuganGordon test. Instead, it distilled froin those cases the policies underlying the sovereign immunity doctrine and, using an undue-judicial-interference test, ${ }^{75}$ found that the issue before it-contract interpretation-was suitable for judicial review. ${ }^{76}$ According to the court, "the underlying policies of the doctrine of sovereign immunity are [not] so strong here as to require dismissal of this suit."77

Some lower courts also bypassed the Larson test by interpreting

69. 373 U.S. at 58.

70. This is true even when the court enjoins a government agency from continuing some type of action. Perhaps the only time affirmative relief does not operate against the government is when the court grants declaratory relief requiring no government action.

71. See notes $25-28$ supra and accoinpanying text.

72. See text accompanying notes $17-23$ supra.

73. Knox Hill Tenant Council v. Washington, 448 F.2d 1045, 1051 (D.C. Cir. 1971).

74. 445 F.2d 1207 (4th Cir. 1971).

75. See text accoinpanying notes 27-31 supra.

76. $445 \mathrm{~F} .2 \mathrm{~d}$ at 1214.

77. Id. 
footnote 11 in Larson $^{78}$ to inean that sovereign immunity may, but need not, bar relief if the relief sought would work affirmatively against the sovereign. ${ }^{79}$ One court noted that the footnote said that a suit may fail, but not that it must fail. 80

Legal scholars have criticized the Larson test. ${ }^{81}$ Professor Davis denounced the Larson maze of legal fictions:

When you sue the government for specific relief or for a declaratory judgment, you must falsely pretend . . . that the suit is not against the government but that it is against an officer. You may get relief against the sovereign if, but only if, you falsely pretend that you are not asking for relief against the sovereign. The judges often will falsely pretend that they are not giving you relief against the sovereign, even though you know and they know, and they know that you know, that the relief is against the sovereign. ${ }^{82}$

Another scholar wrote that one of the chief problems with the sovereign immunity doctrine was that it transforned "everything into a play on words." 83 By 1976 there was much dissatisfaction with the existimg law of sovereign immunity in nonstatutory review actions. The words of Justice Cardozo seemed apt: "[W] hen a rule, after it has been duly tested by experience, has been found to be inconsistent with the sense of justice or . . . the social welfare, there should be less hesitation in frank avowal and full abandonment." 84

78. 337 U.S. at 691 n.l1. The Court stated:

[A] suit may fail, as one against the sovereign, even if it is claimed that the officer being sued has acted unconstitutionally or beyond statutory powers, if the relief requested can not be granted by merely ordering cessation of conduct complained of but will require affirmative action by the sovereign or the disposition of unquestionably sovereign property.

Id. (citing North Carolina v. Temple, 134 U.S. 22 (1890)).

79. See Schlafly v. Volpe, 495 F.2d 273 (7th Cir. 1974). The court noted that sovereign immunity bars suit when "[t]o do otherwise would impose 'an intolerable burden on governmental functions, outweighing any consideration of private harm," " Id. at 280. See also Knox Hill Tenant Council v. Washington, 448 F.2d 1045, $1051-52$ (D.C. Cir. 1977); State Highway Comm'n v. Volpe, 479 F.2d 1099, 1123 (8th Cir. 1973); Washington v. Udall, 417 F.2d 1310, 1317-18 (9th Cir. 1969).

80. Washington v. Udall, 417 F.2d 1310, 1317-18 (9th Cir. 1969).

81. L. JAFFE, supra note 16, at 200; Byse, supra note 2, at 1485-88; Carrow, Sovereign Immunity in Administrative Law-A New Diagnosis, 9 J. PuB. L. 1 (1960); Cramton, supra note 3, at 404 16; Davis, supra note 23, at 404-16; Scalia, Sovereign Immunity and Nonstatutory Review of Federal Administrative Action: Some Conclusions from the Public-Lands Cases, 68 MICH. L. REv. 867, 87282 (1970).

82. K. DAvis, supra note $22, \S 27.01$, at 925 .

83. Carrow, supra note 81, at 22 (letter to Carrow from Professor Walter Gellhorn).

84. B. Cardozo, The Nature of the Judicial Process 150 (1921), quoted in Cartow, supra note 81 , at $21-22$. 


\section{THE 1976 AMENDMENTS TO THE ADMINISTRATIVE Procedure ACT}

Section 10 of the Administrative Procedure Act, which is codified in sections 701 through 706 of Title 5 of the United States Code, gives individuals a right to judicial review of agency action. Section 10(a) states: "A person suffering legal wrong because of agency action, or adversely affected or aggrieved by agency action within the nieaning of a relevant statute, is entitled to judicial review thereof."85 Although section 10 provides a cause of action to a person harmed by federal agency action, the section is not a jurisdictional grant. ${ }^{86}$ Rather, jurisdiction for such actions is based on jurisdictional statutes in the Judicial Code. ${ }^{87}$ Most nonstatutory review actions ${ }^{88}$ fall within the jurisdictional ambit of the federal question statute ${ }^{89}$ or the mandamus statute. ${ }^{90}$

In 1976 section 10 of the Administrative Procedure Act ${ }^{91}$ was amended, as were the federal question ${ }^{92}$ and venue provisions ${ }^{93}$ of the Judicial Code. The purpose of the amendinents was to "remove three

85. 5 U.S.C. \& 702 (1976).

86. See notes $108-11$ infra and accompanying text.

87. 28 U.S.C. $\S \S 1330-1363$ (1976).

88. See, e.g., Legal Aid Soc'y v. Brennan, 608 F.2d 1319 (9th Cir. 1979), cert. denied, $100 \mathrm{~S}$. Ct. 3010 (1980); Jaffee v. United States, 592 F.2d 712 (3d Cir.), cert. denied, 441 U.S. 961 (1979); Hill v. United States, 571 F.2d 1098 (9th Cir. 1978); Schlafly v. Volpe, 495 F.2d 273 (7th Cir. 1974); Knox Hill Tenant Conncil v. Washington, 448 F.2d 1045 (D.C. Cir. 1971); Littel v. Morton, 445 F.2d 1207 (4th Cir. 1971).

89. 28 U.S.C. $\$ 1331$ (1976).

90. Id. $\S 1361$.

91. 5 U.S.C. $\$ \$ 701-706$ (1976). Section 702 as amended now reads:

A person suffering legal wrong because of agency action, or adversely affected or aggrieved by agency action within the meaning of a relevant statute, is entitled to judicial review thereof. An action in a court of the United States seeking relief other that (sic) money damages and stating a claim that an agency or an officer or employee thereof acted or failed to act in an official capacity or under color of legal authority shall not be dismissed nor relief therein be denied on the ground that it is against the United States or that the United States is an indispensable party. The United States may be named as a defendant in any such action, and a judgment or decree may be entered against the United States: Provided, That any mandatory or injunctive decree shall specify the Federal officer or officers (by name or title), and their successors in office, personally responsible for compliance. Nothing herein (I) affects other limitations on judicial review or the power or duty of the court to dismiss any action or deny relief on any other appropriate legal or equitable grounds; or (2) confers authority to grant relief if any other statute that grants consent to suit expressly or impliedly forbids the relief which is sought.

Id. $\$ 702$ (1976) (eniphasis indicates portions added by the amendnents, Act of Oct. 21, 1976,

Pub. L. No. 94-574, § 1, 90 Stat. 2721). Section 703 as antended now provides:

The form of proceedimg for judicial review is the special statutory review proceeding relevant to the subject matter in a court specifled by statute or, in the absence or madequacy thereof, any applicable forn of legal action, includimg actions for declaratory judgments or writs or prohibitory or nuandatory injunction or habeas corpus, in a court of competent jurisdiction. If no special statutory review proceeding is applicable, the action for judicial review may be brought against the United States, the agency by its official title, or the appropriate officer. Except to the extent that prior, adequate, and exclusive opportu- 
technical barriers to the consideration on the merits of citizens' complaints against the Federal Government, its agencies or einployees."94 The amendments abolislied sovereign immunity in nonstatutory suits seeking relief other than money damages, ${ }^{95}$ allowed the United States itself to be named as a party defendant, ${ }^{96}$ allowed third party defendants to be jomed in such suits, ${ }^{97}$ and eliminated the jurisdictional amount requirement in suits against the United States and its officers. ${ }^{98}$

It is important to note what these changes were intended to accoinplish. Sovereign immunity was eliminated in suits for specific relief only. "Thus the limitations on the recovery of nioney daniages contained in the Federal Tort Claims Act, the Tucker Act, or similar statutes [were] unaffected."99 Moreover, Congress eradicated sovereign immunity only in cases involving those agencies and agency functions defined $\mathrm{m}$ section $701(\mathrm{~b})(1)$ of Title 5.100 Other agencies and agency

nity for judicial review is provided by law, agency action is subject to judicial review in civil or criminal proceedings for judicial enforcement.

5 U.S.C. $\$ 703$ (1976) (emphasis indicates portions added by the amendments, Act of Oct. 21 , 1976, Pub. L. No. 94-574, § 1, 90 Stat. 2121).

92. 28 U.S.C. $\$ 1331$ (1976). Section 1331(a) as amended provides:

The district courts shall have origmal jurisdiction of all civil actions wherein the matter in controversy exeeds the sum or value of $\$ 10,000$, exclusive of interest and costs, and arises under the Constitution, laws, or treaties of the United States, except that no such sum or value shall be required in any such action brought against the United States, any agency thereof, or any officer or employee thereof in his official capacity.

Id. $\$ 1331$ (a) (1976) (emphasis indicates portions added by the amendments, Act of Oct. 21, 1976, Pub. L. No. 94-574, § 2, 90 Stat. 2721).

93. 28 U.S.C. $\$ 1391$ (1976). According to section 1391(e) as amended:

A civil action in which a defendant is an officer or employee of the United States or any agency thereof acting in his official Capacity or under color of legal authority, or an agency of the United States, or the United States, may, except as otherwise provided by law, be brought in any judicial district in which (1) a defendant in the action resides, or (2) the cause of action arose, or (3) any real property involved in the action is situated, or (4) the plaimtiff resides if no real property is imvolved in the action. Additional persons may be joined as parties to such action in accordance with the Federal Rules of Civil Procedure and with such other venue requirements as would be applicable if the United States or one of its officers, employees, or agencies were not a party.

Id. $\$ 1391$ (e) (1976) (emphasis indicates portions added by the amendments, Act of Oct. 21, 1976, Pub. L. No. 94-574, § 3, 90 Stat. 2721).

94. H.R. REP. No. 94-1656, supra note 8, at 3, reprinted in [1976] U.S. CODE CONG. \& AD. NEWS 6123.

95. 5 U.S.C. $\$ 702$ (1976).

96. Id. $\$ 703$.

97. 28 U.S.C. $\$ 1391(\mathrm{e})(1976)$.

98. Id. $\$ 1331(\mathrm{a})$.

99. H.R. REP. No. 94-1656, supra note 8, at 11, reprinted in [1976] U.S. CODE CONG. \& AD. NEws 6131. The statute exphitly excludes actions for money damages, thus not exposing the government to greater financial burden.

100. Id. 5 U.S.C. $\$ 701(\mathrm{~b})(1)(1976)$ defines agency as:

[E]ach authority of the Government of the United States, whether or not it is within or subject to review by another agency, but does not include- 
actions are not within the purview of section 10 of the Administrative Procedure Act and judicial review of the actions of those agencies is possible only if Congress has specifically provided for such review by statute. ${ }^{101}$ The 1976 amendments also left open the question of jurisdiction. There is no indication in the language of the amendments that section 10 is now to be construed as a grant of jurisdiction. ${ }^{102}$

The amendments were not intended to change existimg law pertaining to other types of judicial review. This is explicitly set out in the provision: "Nothing herem . . . affects other limitations on judicial review or the power or duty of the court to dismiss any action or deny rehef on any other appropriate legal or equitable ground."103 Thus, though sovereign immunity is partially eliminated, other bars to suit remain mtact. The House Report on the annendments notes seven distimct grounds that would still require disınissal of a suit against the government:

(1) extraordinary relief should not be granted because of the hardship to the defendant or to the public ("balancing the equities") or because the plaintiff has an adequate remedy at law; (2) action coinmitted to agency discretion; (3) express or implied preclusion of judicial review; (4) standing; (5) ripeness; (6) failure to exhaust administrative remedies; and (7) an exclusive alternative remedy. ${ }^{104}$

The legislative history of the 1976 amendments shows that Congress's main intent was to eliminate the confusion reflected in the case law concerning the sovereigu immunity doctrine. ${ }^{105}$ The Judiciary

\footnotetext{
(A) the Congress;

(B) the courts of the United States;

(C) the governments of the territories or possessions of the United States;

(D) the government of the District of Columbia;

(E) agencies composed of representatives of the parties or of representatives of organizations of the parties to the disputes determined by them;

(F) courts martial and military commissions;

(G) military authority exercised in the field in time of war or in occupied territory;

or

(H) functions conferred by sections $1738,1739,1743$, and 1744 of title 12; chapter 2 of title 41; or sections 1622, 1844, 1891-1902, and former section 1641(b)(2), of title 50. ...

101. See, e.g., 10 U.S.C. $\S 2207$ (1976) (providing for review of Department of Defense contracts); 15 U.S.C. $\$ 45$ (c) (1976) (providing for review of Federal Trade Commission findings of unfair methods of competition); 15 U.S.C. $\$ 77 \mathrm{vvv}$ (1976) (providing for review of Security and Exchange Commission orders under the Trust Indenture Act of 1939); 29 U.S.C. § 160(e)-(j), (l) (1976) (providing for review of the National Labor Relations Board's findings of unfair labor practices); 45 U.S.C. $\$ 431(f)$ (1976) (providing for review of the Secretary of Transportation's safety rules for railroads).

102. See notes 108-11 infra and accompanying text.

103. 5 U.S.C. $\& 702$ (1976).

104. H.R. REP. No. 94-1656, supra note 8, at 12, reprinted in [1976] U.S. CODE CONG. \& AD. News 6132.

105. For a discussion of the confusion created by the Supreme Court's decisions, see text accompanying notes 49-84 supra.
} 
Committee of the House of Representatives, in recommending the legislation, recognized that the proper test for determining when courts should not entertain a suit against the government is whether there would be undue judicial interference with administrative action: "The committee does not believe that the partial elimination of sovereign immunity, as a barrier to nonstatutory review of Federal administrative action will create undue interference with administrative action. Rather, it will be a safety-value to ensure greater fairness and accountability in the administrative machinery of the Government." 106

The legislative history thus indicates that Congress believed undue judicial interference to be an appropriate modern rationale for sovereign immunity. A plaintiff's suit should be blocked by immunity only when judicial review would constitute undue interference or violate the separation-of-powers doctrine. Nonetlieless, courts liave not always interpreted and applied the amendnients in this manner. ${ }^{107}$

\section{INTERPRETATION OF THE 1976 AMENDMENTS BY FEDERAL COURTS}

Shortly after the enactnient of the 1976 anendnients to the Administrative Procedure Act, the Supreme Court decided that section 10 does not grant jurisdiction in addition to providing plaintiffs with a cause of action for review of agency action. The Court's liolding in Califano v. Sanders ${ }^{108}$ settled a conflict among the courts of appeals. ${ }^{109}$ The Court ruled that the federal question statute, ${ }^{110}$ and not section 10 , was the proper jurisdictional predicate for nonstatutory review actions. ${ }^{111}$

The courts of appeals have not, however, agreed upon the extent to which the amendinents actually abolish sovereign immunity in nonstatutory review actions. In Estate of Watson v. Blumenthal 112 the Court of Appeals for the Second Circuit interpreted the 1976 aniendments narrowly and found that a plaintiff's suit could still be blocked under the Larson line of cases. ${ }^{113}$ The plaintiff in Watson sought declaratory re-

106. H.R. ReP. No. 94-1656, supra note 8, at 9, reprinted in [1976] U.S. CoDE CoNG. \& AD. News 6129-30.

107. See text accompanying notes 112-25 infra.

108. 430 U.S. 99, 105 (1977).

109. Compare Pickus v. United States Bd. of Parole, 507 F.2d 1107 (D.C. Cir. 1974), and Bradley v. Weinberger, 483 F.2d 410 (1st Cir. 1973), with Bramblett v. Desobry, 490 F.2d 405 (6th Cir. 1974), and Zimmerman v. United States, 422 F.2d 326 (3d Cir. 1970).

110. 28 U.S.C. $\S 1331$ (1976).

111. 430 U.S. at 105.

112. 586 F.2d 925 (2d Cir. 1978).

113. Id. at 929-32. See text accompanying notes 59-70 supra. 
lief and an order to compel the government to redeem certain United States Treasury Bonds at par value for payment of federal estate taxes. ${ }^{114}$ The plaintiffs asserted jurisdiction under sections 1331 (federal questions), 1361 (mandamus), 1391(e) (venue for suits agamst officers), and 2201(e) (declaratory judgment) of Title 28.115 The actual holding by the court of appeals in Watson was that the district court lacked jurisdiction because the Court of Claims had exclusive jurisdiction under the Tucker Act. ${ }^{116}$ The court of appeals was not satisfied, however, with such a simphistic disposition of the case and decided to address the broader question of sovereign immunity and the 1976 Amendments to the Administrative Procedure Act. ${ }^{117}$ The court began its analysis of the 1976 amendments by finding that nonstatutory review actions under section 1331 were distimct from actions brought under the Administrative Procedure Act. ${ }^{118}$ According to the court, the amendments partially waived sovereign immunity under the Administrative Procedure Act but not under section 1331.119 Furthermore, there was no subject matter jurisdiction under section 10 of the Administrative Procedure Act: ${ }^{120}$ "[T]he aunendments . . . do not provide for

114. Watson, a former United States Ambassador, became conuatose after an accident. His brother, as attorney-in-fact, purchased Treasury bonds, known as Flower bonds, while Watson was comatose. These bonds could be used upon the owner's death to pay federal estate taxes. In this case, since the bonds were purchased while Watson was coniatose, the Bureau of Public Debt refused the tender of the bouds upon Watson's death, claiming the purchase was beyond the brother's authority under a general power of attorney. Upon the Bureau's refusal, the estate sued the Secretary of the Treasury and the Commissioner of the Bureau of Public Debt. Id. at 927-28.

115. 28 U.S.C. $\$ \S 1331,1361,1391(\mathrm{e}), 2201(\mathrm{e})$ (1976). The court of appeals limited its consideration of jurisdiction to the federal question and inandamus statutes. The court found that 28 U.S.C. $\$ \$ 1391(\mathrm{e})$ and 2201 were inapplicable. 586 F.2d at 928 . Section 1391(e) is a venue statute and the Declaratory Judgment Act, 28 U.S.C. $\$ 2201$ (1976), "does not provide an independent basis for jurisdiction but simply increases the renuedies available to a litigant. . . ." $586 \mathrm{~F} .2 \mathrm{~d}$ at 928.

116. 586 F.2d at 929 . The Tucker Act provides in pertinent part:

The Court of Claims shall have jurisdiction to render judgment upon any claim against the United States founded either upon the Constitution, or any Act of Congress, or any regulation of an executive department, or upon any express or implied contract with the United States, or for liquidated or unliquidated damages in cases not sounding in tort.

28 U.S.C. $\$ 1491$ (1976).

117. 586 F.2d at 929 . The court said "this analysis may be simplistic if it involves simply an atteinpt to pigeonhole the case under one label . . . or another . . . in the lope that the pigeonholing itself will solve the problein. . . . A more sophisticated analysis inust also take into account the matter of sovereign immunity."

118. Id. at 932. The court's rationale for this interesting conclusion was that different sections of the amendments' legislative history discussed the Administrative Procedure Act and section 1331. Id.

119. Id.

120. Id. In finding no subject inatter jurisdiction under section 10 of the Administrative Procedure Act, 5 U.S.C. $\$ \S 701-706$ (1976), the court followed the loolding in Califano v. Sanders, 430 U.S. 99 (1977). See notes 109-11 supra and accoinpanying text. 
jurisdiction but only make it clear that sovereign immunity will not be a defense im actions im which jurisdiction does exist . . ."121 Under the court's interpretation of the section 10 amendments, therefore, sovereign immunity can still bar a plaimtiff's suit by precludimg a court from exercising jurisdiction under the relevant jurisdictional statute.

Next, after examining the plaimtiff's claim, the court held that it had no jurisdiction under section 1331. According to the court, Larson, Dugan, and Gordon were controlling; therefore a suit against the government could not be permitted if the remedy sought would act against the public treasury. ${ }^{122}$ Quoting an unreported district court case, Estate of Pingree v. Blumenthal, ${ }^{123}$ the court found that an order compelling government redemption of the bonds would operate agamst the government and diminish the public treasury. ${ }^{124}$ The plaintiffs were therefore precluded from receiving nonstatutory review of their claim. Finding no express statutory waiver that would otherwise permit the plaintiffs to proceed, the court dismissed the case for lack of jurisdiction. ${ }^{125}$

The Watson analysis is unsatisfactory because it ignores the logic of Califano v. Sanders ${ }^{126}$ and nullifies the effect of the amendments to section 10. Under the Sanders rationale, although section 10 of the Administrative Procedure Act is not itself a grant of jurisdiction, a nonstatutory review action can be brought under section 1331.127 The cause of action would be based on the amended section 702 (section 10(a) of the Administrative Procedure Act) ${ }^{128}$ which eliminates sovereign immunity as a defense. Watson, however, denies any connection between the two provisions. If a case is brought using section 1331 as a jurisdictional predicate, Watson insists that Larson applies, regardless of whether the action is framed in terms of a section 10 cause of action.

121. 586 F.2d at 932. The remainder of the court's opinion focuses on the relationship between the Tucker Act and the Administrative Procedure Act as aunended. The court found that the Tucker Act applied to the case and that Congress intended it to be an exclusive remedy. Id. at 933. The amended section 10 of the Administrative Procedure Act explicitly states that a court cannot grant relief under section 702 of the Act if another statute expressly or impliedly forbids the relief. Section 702 is set out in full at note 91 supra. This part of the court's imterpretation is sound. Congress did not intend to eliminate sovereign immunity under section 702 where monetary rehef is sought and exclusive jurisdiction is granted under another statute. See notes 99-100 supra and accompanying text.

122. See 586 F.2d at 929-31.

123. No. Civ-77-3-ND (D. Me. Mar. 3, 1978).

124. 586 F.2d at 930 .

125. 586 F.2d at 935.

126. 430 U.S. 99 (1977).

127. See text accompanying notes 108-11 supra.

128. 5 U.S.C. $\$ 702$ (1976). 
This analysis renders superfluous congressional efforts to make it easier to bring nonstatutory review actions.

The Watson analysis is also inconsistent with the modern rationale for sovereign immunity. Under Watson a plaintiff's contract or bond redemption action is barred even though the courts are quite capable of deciding those questions. The inodern rationale for immunity, however, indicates that courts should permit such actions. An order compelling redemption of the treasury bonds in Watson would not have interfered with the administration of a government program since the prograin in question was expressly designed to redeem bonds for estate tax purposes. ${ }^{129}$

District courts within the Second Circuit have followed the court of appeals' opinion in Watson ${ }^{130}$ Courts of appeals in other circuits, however, have not fallen in line. The interpretations of the 1976 annendinents by the Courts of Appeals for the Third and Ninth Circuits have been consistent with the plain congressional intent behind those annendinents. ${ }^{131}$ The leading case is Jaffee $v$. United States, ${ }^{132}$ which, in part, imvolved a class action suit against the United States arising out of the Army's testing of an atoinic bomb. ${ }^{133}$ Jaffee sought two types of relief on behalf of a class composed of all Army personnel who were present during the test explosion. Jaffee sought to warn all class members of the potential medical risks facing them and to force the governinent to pay for or subsidize medical care for class members. ${ }^{134}$ The district court disinissed the class action count because of sovereign iminuinity.

The court of appeals concluded that because the Federal Tort Claims Act ${ }^{135}$ did not cover the suit, Jaffee could bring his suit only if

129. See 31 U.S.C. $\$ 752$ (1976). It must be noted, however, that there may be a jurisdictional conflict between the district court and the Court of Claims. See notes 116 \& 121 supra.

130. See Sharrock v. Harris, 473 F. Supp. 1173 (S.D.N.Y. 1979); Sterling Nat'l Bank \& Trust Co. v. Teltronics Servs., Inc., 471 F. Supp. 182 (S.D.N.Y. 1979).

131. H.R. REP. No. 94-1656, supra note 8, at 3, 6, 9, reprinted in [1976] U.S. CODE CONG. \& AD. NEws 6123, 6126, 6129.

132. 592 F.2d 712 (3d Cir. 1979).

133. Jaffee was serving in the Army in 1953 at Camp Desert Rock, Nevada, when the Army tested a nuclear device. Jaffee alleged that he and others were ordered to stand in a field near the site of the explosion without protection from radiation. Jaffee and others were exposed to massive doses of radiation. Jaffee alleged that this exposure caused him to develop inoperable cancer. Jaffee and his wife brought a four-count suit against the United States. Three counts were claims for noney damages; the fourth count was brought in the form of a class action. 592 F.2d at 714 .

134. The district court retaimed jurisdiction over the first three counts of the Jaffees' complaint. Id.

135. The Federal Tort Claims Act, 28 U.S.C. $\$ 81346(b), 2671-2680$ (1976), does not provide a cause of action for mjuries to servicenten arising out of activity incident to service. See Feres v. United States, 340 U.S. 135 (1950). 
Congress had waived the government's immunity by some other statute. ${ }^{136}$ The court found that Congress intended that section 702, "under some circumstances, would waive sovereign immunity."137 Exphicitly disagreemg with the Watson decision, the court held that "section 702, when it applies, waives sovereign immunity in 'nonstatutory' review of agency action under section 1331."138

Before both Jaffee and Watson, the Court of Appeals for the Nimth Circuit decided Hill $v$. United States. ${ }^{139}$ The plaimtiff in Hill sought a writ of mandamus, declaratory relief, and damages for the refusal of the Army and the Civil Service Commission to convert him to career-conditional status during temporary civilian employment im the Army. He asserted jurisdiction under sections 1331 and 1361. The district court had dismissed the case on sovereign immunity grounds. The Court of Appeals for the Ninth Circuit held that the 1976 amendments operated retroactively to lift the bar of sovereign immunity for those parts of the claim seeking declaratory relief and a writ of mandamus. ${ }^{140}$ Addressing the effect of the amendments on sovereign immumity, the court concluded: "This statute is cast as a blanket waiver of sovereign immunity as to a broad category of actions against the government, and by its terins it certainly mcludes the non-monetary relief sought by Hill." 141

The Court of Appeals for the Nimth Circuit, in Legal Aid Society v. Brennan, ${ }^{142}$ recently reaffirmed its decision that the 1976 amendments have abolished sovereign immunity in nonstatutory review actions based on section 1331. A number of recent district court cases have also followed the Jaffee-Hill reasoning. ${ }^{143}$ Unlike Watson, Jaffee and

136. 592 F.2d at 716,718 .

137. Id.

138. Id. The court then addressed whether the specific relief applied for came under section 702. It lield that the request for subsidies for medical costs was a money damages claim; section 702 thus did not apply and sovereign immunity barred the claim. The section of the complaint asking for a warning to class members, lowever, was within section 702 as a form of equitable relief. Moreover, the Army came within section 701(b)(1)'s definition of "agency," making its actious reviewable under section 702. See note 100 supra. The definition of agency under section 701(b)(1) excludes the military only if the action arises "in the field or at time of war." The plaintiff in Jaffee sought relief for the government's failure to act in the years following the nuclear testing, thus the section 701(b)(1) exclusion did not apply. 592 F.2d at 720.

139. 571 F.2d 1098 (9th Cir. 1978).

140. Id. at 1102 .

141. Id. The court lield, however, that the suit would still be defeated because there was no substantive right on whicl to base relief. The court relied on Umited States v. Testan, 424 U.S. 392 (1976).

142. 608 F.2d 1319 (9th Cir. 1979), cert. denied, 100 S. Ct. 3010 (1980).

143. Collyard v. Washington Capitals, 477 F. Supp. 1247 (D. Minn. 1979); Neal v. Secretary of Navy, 472 F. Supp. 763 (E.D. Pa. 1979); Saltzman v. Stetson, 472 F. Supp. 848 (W.D. Pa. 1979). 
Hill effectuate the congressional intent to abolish sovereign immunity unless there is good reason for the doctrine to bar a suit. ${ }^{144}$ Jaffee and Hill thus comport witl the modern rationale for sovereign immumity. ${ }^{145}$ The Supreme Court, lowever, lias yet to resolve the dispute between the courts of appeals.

\section{Further Action to INSURe COMPLiANCE With CONGRESSIONAL INTENT}

Given the split among the courts of appeals concerning the proper imterpretation of the 1976 amendments, the status of the sovereign immunity doctrine remains uncertain. Congress's purpose in passimg the amendments was to make it easier to sue the governinent for non-inonetary, specific relief. 146 The Court of Appeals for the Second Circuit's interpretation in Watson frustrates this purpose by reinstituting the fiction of the ultra vires action agamst governinent officers and by forcing plaimtiffs to fraine their requests for relief so as not to operate against the governinent.

This section of the comment suggests several ways for the courts and Congress to effectuate the congressional purposes behind the amendments and to alleviate the problems that contmue to surround the sovereign immunity doctrine.

\section{A. Supreme Court Review.}

The best approach to accomplishing the goals of the 1976 amendments would be for the Supreme Court to resolve the conflict among the circuits that Watson and Jaffee created. A case such as Sharrock $v$. Harris, ${ }^{147}$ for example, which follows the Watson approacli, would provide the Court with an opportunity to resolve the conflict by explicitly repudiating Watson and adopting the sounder rationale of the Jaffee court. The plaimtiff in Sharrock was a tenant in a federally assisted lousing project. He claimed that his lease failed to contain certain provisions mandated by the Department of Housing and Urban Development, and sought declaratory and injunctive relief against the Secretary of Housing and Urban Development. The plaintiff asserted jurisdiction based on section 1331 and framed the suit as a nonstatutory review

The Court of Appeals for the Third Circuit recently reaffirmed its decision in Jaffee in National Sea Clammers Assoc. v. City of New York, 616 F.2d 1222 (3d Cir. 1980).

144. Sce notes 105-06 supra and accompanying text.

145. See text accompanying notes 24-36 supra.

146. See note 121 supra.

147. 473 F. Supp. 1173 (S.D.N.Y. 1979). See also Doe v. United States Civil Serv. Comm'n, 483 F. Supp. 539 (S.D.N.Y. 1980). 
action under section 702. Rejecting the plaintiff's jurisdictional argument based on Jaffee, the district court dismissed the case on sovereign immunity grounds, relying on Watson. ${ }^{148}$ Accepting a case such as Sharrock from the court of appeals would give the Supreme Court a chance to review both Jaffee and Watson and, by rejecting the Second Circuit's view, an opportunity to reach the proper result.

Alternatively, the Court could overrule its holding in Califano $v$. Sanders ${ }^{149}$ that section 702 is not an independent grant of jurisdiction. This would side-step the Jaffee-Watson problen because jurisdiction could then be based on a statute containing an explicit waiver of sovereign immunity. It is highly unlikely, however, that the Supreme Court would overrule Califano v. Sanders; the case is fairly recent and the Court squarely decided the question of the proper jurisdictional predicate for a nonstatutory review action. ${ }^{150}$

Ultimately, the Supreme Court could aid in effectuating the congressional purpose behind the 1976 amendments by adopting the undue-judicial-imterference and separation-of-powers tests. ${ }^{151}$ The Court could outline a list of considerations for lower courts to balance when deciding whether Congress intended to waive sovereign immunity in a specific suit. The considerations favoring a finding of congressional waiver would be the nature of the harm the plaintiff alleges, ${ }^{152}$ the type of rehef he seeks, and whether the case presents a question that courts are especially qualified to answer. Considerations indicating that Congress did not intend to waive sovereign immunity would include the degree of interference that comphance with the requested court order would have on a government program and whether the action con1plained of is of the type the agency in question can handle more readily than the courts could.

Optimally, the Supreme Court would both reject the Watson decision and explicitly adopt the undue-judicial-interference test. Rejecting Watson would indicate that nonstatutory review actions under section 702 are properly based on jurisdiction conferred by the federal question statute. ${ }^{153}$ Adopting the undue-judicial-interference test

148. 473 F. Supp. at 1176: "[T] his court believes that the Second Circuit's clear pronouncement cannot be ignored."

149. See notes 108-11 supra and accompanying text.

150. See text accompanying note 111 supra.

151. Congress relied upon these tests im enacting the amendments. See notes 105-06 supra and accompanying text.

152. The more egregious the government action, the stronger the presumption of congressional waiver. In a case like Jaffee, in which the government failed to warn the servicemen of a grave danger, there would be a strong presumption in favor of a waiver of sovereign immunity.

153. 28 U.S.C. \& 1331 (1976). 
would give judges discretion within certain guidelines to determine whether section 702 provides a particular cause of action..$^{154}$

\section{B. Further Congressional Action.}

Congressional action to further effectuate the purposes of the original 1976 amendments would parallel the suggestions made above in regard to Supreme Court review. Congress could amend section 702 again to make it a grant of jurisdiction for district court review of agency action. This would be a statutory overruling of Califano $v$. Sanders. The legislation could make it clear that section 702 would provide the basis for all nonstatutory review of administrative action. Sovereign immumity would still be eliminated in suits for non-monetary specific relief, but other barriers to suit-such as the existence of an adequate remedy at law, standing, or failure to exhaust administrative remedies ${ }^{155}$-would remain intact.

This appears to be the inost logical solution to the problem. Cases such as Jaffee were decided on the basis of statutory interpretation; an exphicit statutory grant of jurisdiction would be dispositive to even the most hiteral-minded judges. The courts would then be able to focus on problems of judicial review of administrative actions and not on the technical problems of jurisdiction.

Alternatively, Congress could amend Section 1331 to eliminate sovereign immunity under that statute. This is a more drastic solution than amending section 702; it would probably result in a plethora of suits that Congress still intends to bar through sovereign immunity. These types of suits would include actions for money damages, contract actions, ${ }^{156}$ and actions against agencies otherwise exempt froin judicial review. ${ }^{157}$ The first two types of actions are relegated to the jurisdiction of the Court of Claims under the Tucker Act; ${ }^{158}$ the last type of suit is barred because of the nature of the agency involved and because private suits would result in undue judicial interference with those agencies, thus violating the constitutional doctrine of separation of powers. An amended section 1331 would have to contain highly techincal provisions making it clear that sovereign immunity would continue to bar those types of actions.

154. See notes 99-104 supra and accompanying text. See also notes 149-50 supra and accompanying text.

155. See notes 103-04 supra and accompanying text.

156. The Tucker Act is the exclusive grant of jurisdiction for suits based on government contracts. See notes $41 \& 99$ supra and accompanying text.

157. See note 100 supra for the definition of agency under the Administrative Procedure Act, 5 U.S.C. $\S 701(b)(1)(1976)$.

158. 28 U.S.C. \& 1491 (1976). 
One final suggestion is for Congress to add a jurisdictional statute to the Judicial Code. This statute would grant jurisdiction to the district courts to hear all suits against the government or its employees that allege agency impropriety or illegal agency action and that seek non-monetary specific rehef. This new statute would be the basis for all nonstatutory review actions. Explicit language in such a statute would eliminate many of the problems discussed above with regard to amending section 1331 .

It is highly unlikely, however, that Congress will take any action in the near future. Congress took almost ten years to act on the original suggestion to amend the Administrative Procedure Act. ${ }^{159}$ Further amendment of the Act might take as long. The Supreme Court should therefore take the mitial steps to resolve the problems this comment examines. Such action is necessary to ensure rational application of the doctrine of sovereign immunity.

\section{CONCLUSION}

Sovereign immunity as a bar to suits against the United States government has persisted for almost one hundred and fifty years. ${ }^{160}$ The courts have devised ways to circumvent the doctrine by creating the legal fiction of ultra vires suits against government officers. In its earliest form a court would have jurisdiction over an ultra vires action if the court were competent to decide the issues in the case. ${ }^{161}$ The Supreme Court later changed this. In a series of cases beginning with Larson v. Domestic \& Foreign Commerce Corp. ${ }^{162}$ the Court held that an ultra vires action could not be maintained if the affirmative relief sought by a plaintiff would "operate" against the sovereign. ${ }^{163}$ Courts and cominentators, however, have found hitle justification for the continued apphication of the Larson rationale in many cases.

The modern rationale for sovereign immunity suggests that the doctrime should preclude a plaintiff's suit only when judicial review would violate the separation-of-powers requirement or constitute un-

159. Administrative Procedure Act Amendments of 1976: Hearings on S.800 Before the Subcomm. on Administrative Practice and Procedure of the Senate Comm. on the Judiciary, 94th Cong., 2d Sess. 186 (1976) (statement of the Federal Bar Association). The original impetus for the 1976 amendments was a 1968 recommendation by the Administrative Conference Committee on Judicial Review. The full Administrative Conference adopted the recommendation in 1969. 38 U.S.L.W. 2242 (1969). The Senate began hearings on a proposed bill in 1970, but the Department of Justice oppesed the bill and it was defeated. Hearings on S.800, supra, at 186.

160. See United States v. McLemore, 45 U.S. (4 How.) 286 (1846).

161. United States v. Lee, 106 U.S. 196 (1882). See notes 50-57 supra and accompanying text.

162. 337 U.S. 682 (1949).

163. See notes $59-70$ supra and accompanying text. 
due judicial interference with the official actions of the government. Congress followed the modern rationale for the doctrine in amending the Administrative Procedure Act, thereby eliminating sovereign iminunity in inost suits against the government brought under the Act.

The courts, however, have struggled with the congressional amendments and disagree about their effect. The Court of Appeals for the Second Circuit in Estate of Watson v. Blumenthal ${ }^{164}$ virtually interpreted the amendments out of existence and reinstituted the Larson rationale. The Court of Appeals for the Third Circuit, in Jaffee $v$. United States, ${ }^{165}$ correctly interpreted the annendments to allow a private citizen to bring suit agamst the government if such a suit does not constitute undue judicial interference with any agency program. The controversy continues as district courts are faced with suits against the government. 166

Congress's intent in amending section 10 of the Administrative Procedure Act is clear: sovereign immunity is eliminated as a bar to suit against an agency when such a suit will not unduly interfere with a government program. Further action by either the Supreme Court or Congress is needed, however, to insure that sovereign immunity is invoked according to the nodern rationale for its existence.

Sharon J. Kronish

164. 586 F.2d 925 (2d Cir. 1978).

165. 592 F.2d 712 (3d Cir. 1979), cert. denied, 441 U.S. 961 (1979).

166. See notes 143 \& 147 supra. 